\title{
Pengaruh Kegiatan Literasi dalam Peningkatan Minat Baca Siswa Kelas VIII SMP Negeri 2 Kota Ternate
}

\author{
Sasmayunita \\ Univesitas Khairun Ternate \\ mrsasmayunita@yahoo.com
}

\begin{abstract}
Abstrak
Peneltian ini mengulik seputar minat baca pada siswa kelas VIII SMP Negeri 2 Kota Ternate, yang dapat ditumbuhkan melalui kegiatan literasi. Penelitian ini menggunakan pendekatan kuantitatif yang berlokasi pada SMP Negeri 2 Kota Ternate. Waktu penelitian dimulai pada tanggal 19 November sampai dengan 19 Desember 2019 dan disesuaikan dengan jadwal mata pelajaran bahasa Indonesia yang berlaku di sekolah. Pengambilan data dilakukan dengan cara observasi, wawancara, dan tes. Penelitian ini menyimpulkan hasil bahwa kegiatan literasi terhadap minat baca pada siswa kelas VIII SMP Negeri 2 Kota Ternate sangat cukup. Pengaruh kegiatan literasi terhadap minat baca siswa kelas VIII SMP Negeri 2 Kota Ternate memiliki pengaruh sesuai dengan hasil data, menunjukan bahwa hasil tes siswa dengan interval nilai 60$69 \%$ atau sesuai pada aspek kesesuaian antara perencanaan dan pelaksanaan kegiatan literasi terdapat 17 responden yang sesuai dan 10 siswa yang tidak sesuai 30-39\%. Aspek kelamaan kegiatan literasi pada pengaruh kegiatan literasi terhadap minat baca dapat dipersentasikan menjadi 56\% atau interval nilai 50-59 terdapat 15 responden yang sesuai, dan 12 responden yang tidak sesuai $44 \%$. Aspek perkembangan hasil kemampuan membaca siswa 16 responden sesuai atau interval nilai 50-59\% dan 11 responden yang tidak sesuai dengan interval nilai 4049\%. Dan aspek perencanaan ke tahap selanjutnya terdapat 15 responden yang sesuai atau interval nilai 50-59\% dan 12 responden dengan kualifikasi nilai $40-49 \%$ yang tidak sesuai. Dengan demikian, scara keseluruhan dari empat aspek dengan interval nilai dengan persentase dapat dikategorikan "sedang". Pencapaian tujuan pendidikan adalah keinginan semua orang baik pendidik maupun peserta didik. Olehnya itu, dalam pebelajaran yang perlu diperhatikan adalah selain peran guru juga peran siswa yang perlu diperhatikan, agar pencapaian tujuan pembelajaran terutama minat baca bisa dinikmati dan dipahami oleh peserta didik.
\end{abstract}

Kata Kunci: Bahasa, Literasi, Membaca

\section{Pendahuluan}

Bahasa terdiri dari Unsur-unsur atau komponen yang secara teratur tersusun menurut pola tertentu, (Chaer, 2012: 20). Empat keterampilan berbahasa saling berhubungan satu sama lain dan memiliki perannya masingmasing. Kemampuan membaca mempunyai peran dan menjadi salah satu kunci dalam kesuksesan kehidupan setiap orang, karena setiap informasi dan pengetahuan yang diperoleh tidak terlepas dari kegiatan membaca. Membaca adalah melihat, serta memahami isi dari apa yang tertulis. Diungkapkan oleh (Tarigan, 2008:7) bahwa membaca adalaah suatu proses yang dilakukan serta dipergunakan oleh pembaca untuk memperoleh pesan yang hendak disampaikan oleh peneliti melalui media kata-kata/bahasa tulis. Hal ini yang mendorong anak untuk belajar membaca sejak umur 4 tahun dari orang tua maupun lingkungan sekitarnya.

Perkembangan zaman menuntut setiap orang memiliki kegemaran membaca guna memperoleh pengetahuan dan wawasan yang luas untuk meningkatkan kecerdasanya (Abidin 2017:5). Kemampuan membaca juga digunakan sebagai tolok ukur alam tingkat keberhasilan sejak di sekolah dasar kemampuan membaca menjadi peran penting,. karena tanpa hal tersebut siswa akan mengalami kesulitan membaca pada saat itu dan pada masa yang akan datang (Somadayo, 2012: 12). Setiap proses pembelajaran berbahasa hendaknya lebih diperhatikan agar tepat sasaran dan mampu meningkatkan kemampuan berbahasa siswa. Tarigan (2008: 9) menjelaskan bahwa keterampilan berbahasa terbagi atas empat komponen termasuk di dalamnyaa 
adalah keterampilan membaca yang memiliki banyak manfaat dalam perkembangan berbahasa siswa. Melalui kegiatan membaca siswa mampu memperoleh banyak pengetahuan. Oleh sebab itu, guru sebaiknya memiliki perhatian khusus dalam kompetensi membaca selain manfaatnya yang besar bagi siswa membaca juga merupakan kegiatan yang kompleks. Pada saat ini kegiatan literasi telah dipandang sebagai suatu kebutuhan yang wajib dikuasai oleh setiap siswa di sekolah (Widodo 2015:49). Kompetensi literasi pada kelas tinggi menekankan siswa untuk mampu melakukan analisis secara krisis, seperti melakukan wawancara, pengamatan lingkungan, menulis laporan dan melakukan observasi. Siswa dapat melakukan kegiatan ini dengan cara membuat tulisan pada buku kemudian mempresentasikan di kelas, dengan ini membantu minat baca siswa (Rosidi 2016: 24).

Minat membaca dapat ditumbuhkan pada siswa melalui kegiatan literasi tanpa harus menunggu siswa tersebut mempunyai keterampilan membaca. Adanya rasa senang, rasa puas dalam diri siswa, partisipasi aktif yang tanpa dipaksa, dan lebih menyukai kegiatan tersebut tanpa membandingkan dengan kegiatan lain merupakan tanda adanya kemunculan minat dalam diri siswa 9 (Bastiano, 2014:16). Minat menjadi motivator yang utama dan kuat untuk melakukan suatu aktivitas. Secara umum minat dapat diartikan sebagai kecendrungan yang menyebabkan siswa berusaha melakukan suatu aktivitasaktivitas dalam bidang lain dengan rasa senang dan puas (Hasanah, 2011:32) Minat membaca tidak hanya ketika siswa telah memasuki dunia pendidikan saja, namun ketika ia berada dalam lingkungan keluarga dan sekitarnya minat tersebut langsung diciptakan oleh dirinya sendiri. Namun, minat baca peserta didik begitu berkurang dihampir semua sekolah rasakan (Nurhadi 2000:13)

Budaya membaca perlu ditingkatkan di kalangan siswa kelas VIII SMP Negeri 2 Kota Ternate. Sehubungan dengan itu, untuk meningkatkan minat baca pada siswa kelas VIII SMP Negeri 2 Kota Ternate. Oleh karena itu, digiatkan kegiatan berliterasi dalam Peningkatan Minat Baca siswa di sekolah yang dikembangkan. Hasil penelitian tentang Pembelajaran berbasis literasi dalam konteks kurikulum 2013 yang pernah dilaksanakan oleh peneliti di SMP Negeri 1 Kota Ternate, menunjukkan bahwa kegiatan literasi ini mampu meningkatkan hasil belajar siswa khususnya pada mata pelajaran membaca pada mata pelajaran Bahasa Inggris. Penelitian sejenis juga dilakukan oleh Lawalata dan Sholeh (2019) dengan judul "Pengaruh program literasi terhadap minat baca dan prestasi belajar siswa di SMP Islam Al_Azhar Tulungagung membawa pengaruh positif dan signifikan terhadap minat baca siswa.

Berdasarkan uraian di atas, maka peneliti mengambil judul penelitian yaitu " Pengaruh Kegiatan Literasi dalam Peningkatan Minat Baca Siswa Kelas VIII SMP Negeri 2 Kota Ternate"

\section{Metode Penelitian \\ Jenis Penelitian}

Jenis penelitian ini merupakan penelitian deskriptif dengan menggunakan pendekatan kuantitatif. Jenis penelitian ini bertujuan untuk mendapatkan informasi yang sifatnya memberikan gambaran atau penjelasan tentang suatu gejala atau peristiwa sebagaimana adanya atau sesuai yang terjadi di lapangan. Dalam penelitian ini digambarkan bagaimana kegiatan literasi dapat meninkatkan minat baca siswa di kelas VIII SMP Negeri 2 Kota Ternate. Metode Penelitian kuantitatif adalah suatu proses menemukan pengetahuan yang menggunakan data berupa angka sebagai alat menganalisis keterangan mengenai apa yang ingin diketahui (Kasiram 2008: 149). 


\section{Lokasi dan Waktu Penelitian Lokasi Penelitian}

Adapun lokasi penelitian yang menjadi fokus utama dalam mengumpulkan data adalah SMP Negeri 2 Kota Ternate yang terletak di Kelurahan Dufa-dufa Provinsi Maluku Utara.

\section{Waktu Penelitian}

Waktu penelitian dimulai pada tanggal 19 November sampai dengan 19 Desember 2019 dan disesuaikan dengan jadwal mata pelajaran bahasa Indonesia yang berlaku di sekolah.

\section{Populasi dan Sampel \\ Populasi}

Menurut Arikunto (2006: 130) "Populasi adalah keseluruhan objek penelitian". Penelitian hanya dapat dilakukan bagi populasi terhingga dan subyeknya tidak terlalu banyak. Populasi dalam penelitian ini adalah keseluruhan siswa disekolah SMP Negeri 2 Kota Ternate berjumlah 180 orang.

\section{Sampel}

Menurut Sugiyono (2015: 118) "Sampel adalah bagian dari jumlah dan karakteristik yang dimiliki oleh populasi tersebut". Teknik pengambilan sampel pada penelitian ini menggunakan Purposive Sampling. Teknik sampling yang cukup sering digunakan. Metode ini menggunakan kriteria yang telah dipilih oleh peneliti dalam hal ini sampel yang dipilih adalah siswa kelas VII SMP Negeri Kota Ternate yang berjumlah 27 orang.

\section{Teknik Pengumpulan Data}

Data penelitian ini dikumpulkan dengan cara menggunakan instrumen pengumpul data yaitu peneliti sebagai instrumen utama (Mahsun 2005:49). Peneliti bertindak sebagai pengumpul data melalui teknik observasi, teknik wawancara, dan teknik kuesioner. Instrumen penelitian yang digunakan untuk menjawab rumusan masalah pada penelitian ini adalah observasi, wawancara, dan angket.

\section{Observasi}

Obsevasi dilakukan oleh peneliti untuk mengamati dan sekaligus berpartisipasi dalam suasana dan latar perpustakaan ketika kegiatan literasi minat baca berlangsung. Dengan berpedoman pada lembar pedoman observasi, peneliti mengamati apa yang terjadi dalam proses pelaksanaan kegiatan literasi. Instrumen pedoman observasi digunakan untuk menjawab rumusan masalah nomor 1, dengan hasil data berupa proses pengaruh kegiatan literasi dalam peningkatan minat baca siswa di SMP Negeri 2 Kota Ternate.

\section{Wawancara}

Wawancara dilakukan oleh peneliti yang digunakan untuk mengetahui minat baca siswa sebelum kegiatan literasi. Wawancara dilakukan kepada pengelola perpustakaan yang mengetahui minat baca siswa secara langsung berdasarkan hasil presensi siswa dan pinjaman buku di perpustakaan. Teknik tersebut dilakukan berdasarkan pedoman wawancara. Instrumen yang digunakan untuk menjawab rumusan masalah nomor 2 adalah wawancara untuk mengetahui hasil pengaruh kegiatan literasi dalam peningkatan minat baca siswa kelas VIII SMP Negeri 2 Kota Ternate.

\section{Tes/Angket}

Angket adalah salah satu media yang digunakan peneliti untuk mengumpulkan data dalam penelitian pendidikan maupun penelitian sosial yang paling populer digunakan adalah angket.

Angket digunakan oleh peneliti untuk mengetahui peningkatan minat baca siswa sebelum dan sesudah penerapan kegiatan literasi di sekolah. Instrumen tersebut untuk menjawab rumusan masalah. Jumlah soal 15 butir pertanyaan pilihan ganda. 


\section{Analisis Data, dan Evaluasi}

Adapun analisis data dan evaluasi dalam penelitian ini adalah sebagai berikut.

\section{Analisis Data}

Analisis data sangat berguna untuk mendukung pemecahan masalah yang telah dirumuskan sebelum pelaksanaan kegiatan literasi.

Langkah awal yang dilakukan peneliti adalah memeriksa ulang apakah seluruh informasi yang diperlukan dalam observasi, wawancara, angket, dan jurnal membaca yang diisi siswa menggunakan kualifikasi yang telah ditetapkan oleh peneliti. Kualifikasi tersebut yang berada pada Tabel dibawah ini sebagai berikut:

Tabel 1. Kualifikasi Minat Baca dalam Kegiatan Literasi

\begin{tabular}{cc}
\hline Frekuensi Membaca & Kualifikasi Membaca \\
$1-2 \mathrm{kali} / \mathrm{minggu}$ & Rendah \\
\hline $3-4 \mathrm{kali} / \mathrm{minggu}$ & Sedang \\
\hline $5-6 \mathrm{kali} / \mathrm{minggu}$ & Tinggi \\
\hline
\end{tabular}

Data yang telah didapat tersebut akan disesuaikan hasilnya satu sama lain. Apabila data tersebut tidak sesuai, peneliti harus merefleksi dimana sumber kesalahan ini.

\section{Hasil Penelitian dan Pembahasan Hasil Penelitian}

Setelah data terkumpul melalui tes kemudian pengolahan data. Pengolahan tersebut dilakukan dengan cara mengklarifikasikan data dan kategorisasi data yang sesuai dengan jenisnya. Data dianalisis tingkat peresentase untuk mengetahui pengaruh kegiatan literasi terhadap minat baca siswa kelas VIII SMP Negeri 2 Kota Ternate. Dan klasifikasi data dapat dilihat pada tabel berikut.

Tabel 2. Klasifikasi Data

\begin{tabular}{clccccc}
\hline \multirow{2}{*}{ No } & & \multicolumn{3}{c}{ Pilihan Kategori Jawaban } & Jumlah \\
& & 1 & 2 & 3 & 4 & \\
\hline 1 & NT & 5 & 6 & 1 & 3 & 15 \\
\hline 2 & MR & 5 & 4 & 3 & 3 & 15 \\
\hline 3 & Al & 3 & 3 & 3 & 6 & 15 \\
\hline 4 & AI & 3 & 4 & 1 & 7 & 15 \\
\hline 5 & AA & 7 & 4 & 1 & 3 & 15 \\
\hline 6 & A R & 5 & 4 & 2 & 4 & 15 \\
\hline 7 & CYS & 5 & 6 & 3 & 1 & 15 \\
\hline 8 & DF & 5 & 4 & 2 & 4 & 15 \\
\hline 9 & DA & 5 & 4 & 4 & 2 & 15 \\
\hline 10 & FM & 3 & 5 & 3 & 4 & 15 \\
\hline 11 & IIM & 3 & 5 & 2 & 5 & 15 \\
\hline 12 & JK & 4 & 4 & 4 & 3 & 15 \\
\hline 13 & MGP & 3 & 3 & 3 & 6 & 15 \\
\hline 14 & MH & 2 & 2 & 4 & 7 & 15 \\
\hline 15 & MRA & 6 & 5 & 3 & 1 & 15 \\
\hline 16 & TA & 5 & 4 & 4 & 2 & 15 \\
\hline 17 & NM & 7 & 3 & 1 & 4 & 15 \\
\hline 18 & NP & 3 & 5 & 3 & 4 & 15 \\
\hline \hline
\end{tabular}




\begin{tabular}{|c|c|c|c|c|c|c|}
\hline 19 & NR & 5 & 4 & 4 & 2 & 15 \\
\hline 20 & NRT & 5 & 5 & 2 & 3 & 15 \\
\hline 21 & P E N & 1 & 4 & 3 & 7 & 15 \\
\hline 22 & PS & 4 & 5 & 3 & 3 & 15 \\
\hline 23 & RA & 4 & 4 & 2 & 5 & 15 \\
\hline 24 & Sal & 4 & 5 & 2 & 4 & 15 \\
\hline 25 & SSB & 3 & 5 & 2 & 5 & 15 \\
\hline 26 & SF & 6 & 2 & 3 & 4 & 15 \\
\hline \multirow[t]{3}{*}{27} & Y E P & 5 & 4 & 4 & 2 & 15 \\
\hline & Rata-rata & 4,30 & 4,19 & 2,67 & 3,85 & \\
\hline & Jumlah & 116 & 113 & 72 & 104 & \\
\hline
\end{tabular}

Tabel 3. Rekapitulasi hasil analisis data siswa kelas VIII SMP Negeri 2 Kota Ternate

\begin{tabular}{ccccc}
\hline Aspek & Sesuai & Presentase & Tidak Sesuai & Presentase \\
$\mathbf{1}$ & 17 & $64 \%$ & 10 & $35 \%$ \\
\hline $\mathbf{2}$ & 15 & $67 \%$ & 12 & $32 \%$ \\
\hline $\mathbf{3}$ & 16 & $64 \%$ & 11 & $28 \%$ \\
\hline $\mathbf{4}$ & 15 & $57 \%$ & 12 & $44 \%$ \\
\hline $\begin{array}{c}\text { Jumlah } \\
\text { Rata- } \\
\text { rata }\end{array}$ & \multicolumn{3}{c}{63} & \multicolumn{3}{c}{11,25} \\
\hline
\end{tabular}

\section{Rekapitulasi hasil analisis data siswa SMP Negeri 2 Kota Ternate}

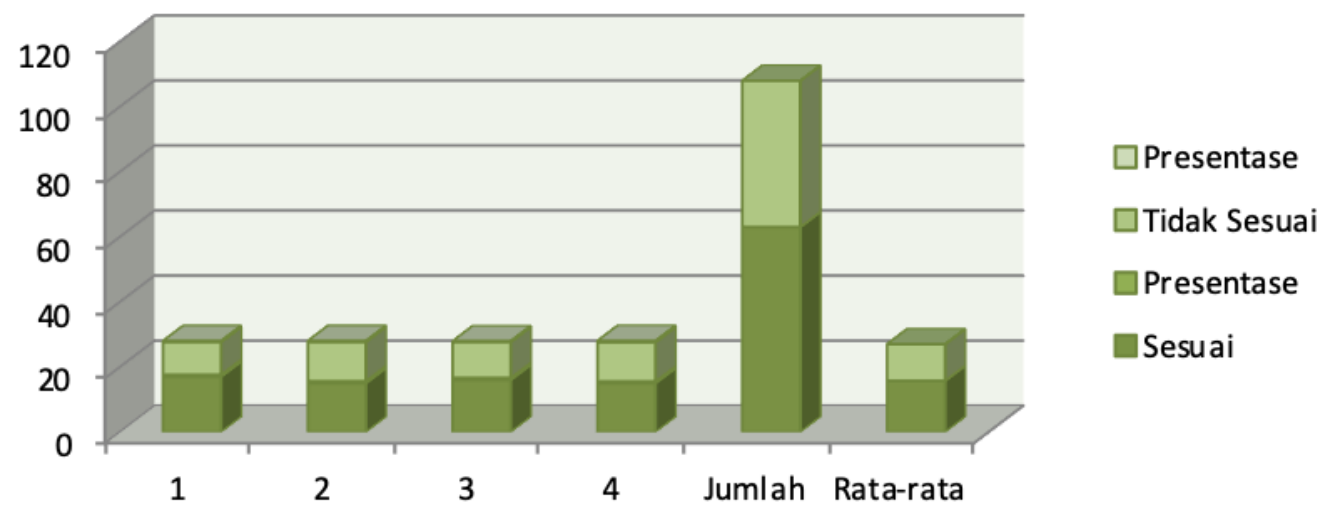

Rekapitulasi hasil analisis data pada tabel 3 di atas, menunjukan bahwa hasil peresentase siswa kelas VIII SMP Negeri 2 Kota Ternate Pengaruh kegiatan literasi terhadap minat baca siswa kelas VIII SMP Negeri 2 Kota Ternate memiliki pengaruh sesuai dengan hasil data, menunjukan bahwa hasil tes siswa dengan interval nilai $60-69 \%$ atau sesuai pada aspek kesesuaian antara perencanaan dan peleksanaan kegiatan literasi terdapat 17 responden yang sesuai dan 10 siswa yang tidak sesuai 30-39\%. Aspek kelamaan kegiatan literasi pada pengaruh kegiatan literasi terhadap minat baca atau dapat dipersentasikan menjadi 56\% atau interval nilai 50-59 terdapat 15 responden yang sesuai, dan 12 responden yang tidak sesuai $44 \%$. Aspek perkembangan hasil kemampuan membaca siswa 16 responden sesuai atau interval nilai 5059\% dan 11 responden yang tidak sesuai dengan interval nilai 40-49\%. Dan aspek perencanaan ke tahap selanjutnya terdapat 15 responden yang sesuai 
atau interval nilai 50-59\% dan 12 responden dengan kualifikasi nilai 40-49\% yang tidak sesuai. Dengan demikian scara keseluruhan dari empat aspek dengan interval nilai dengan persentase dapat dikategorikan "sedang".

\section{Pembahasan}

Kegiatan literasi dalam meningkatkan minat baca siswa merupakan penerapan berbagai cara dan pnggunaan berbagai alat untuk memperoleh informasi tentang sejauhmana hasil belajar peserta didik atau ketercapaian kompetensi. Hasil belajar berupa nilai kualitatif (pernyataan naratif dalam katakata) dan nilai kuantitatif (berupa angka). Tes adalah cara penilaian yang dirancang dan dilaksanakan kepada siswa pada waktu dan tempat tertentu serta kondisi yang memenuhi syarat yang jelas. Oleh karena itu, untuk memperoleh data dalam penelitian ini penulis telah menyiapkan instrumen penelitian berupa angket yang dibagikan kepada siswa atau responden untuk memilih kemungkinan jawaban yang dianggap sesuai dengan pertanyaanpertanyaan yang disiapkan oleh peneliti.

Berdaskan teknik yang dipakai peneliti tersebut, maka data yang menguraikan berdsarkan keterangan dan tafsiran yang sesuai dengan data yang diteliti. Dari hasil tes di mulai pada soal nomor 1 sampai dengan soal nomor 15 yang masuk dalam kategori tinggi terdapat pada soal no (1) dengan interval 74\%, untuk kategori sedang terdapat pada soal no (2), (4), (5), (7), )10), dan (11) dengan skala interval 50\% -59\%. Untuk kategori cukup terdapat pada soal no (12) dengan skala interval 63\%. Sedangkan kategori rendah terdapat pada butiran soal no (6), (13), (14) dan (15) dengan interval 40\% -49\%. Dan untuk kategori sangat rendah terdapat pada butiran soal no (3), (8), (9). Dengan demikian peneliti berkesimpulan berdasarkan kategori dimulai pada butiran soal no 1-15 dengan skala interval terhadap pengaruh kegiatan liiterasi dalam peningkatan minat baca siswa kelas VIII SMP Negeri 2 Kota Ternate dengan 27 siswa sebagai sumber data dikategorikan "Rendah".

\section{Kesimpulan}

Hasil analisis data yang telah diuraikan dalam bab IV, kesimpulan yang dapat dikemukakan sebagai berikut:

1. Proses kegiatan literasi dalam meningkatkan minat baca siswa kelas VIII SMP Negeri 2 Kota Ternate, pada empat aspek yang telah didiskripsikan pada tabel-tabel di atas, kemudian ditetapkan dengan jumlah 64\%dan dapat diketegorikan berpengaruh kegiatan literasi terhadap minat baca pada siswa kelas VIII SMP Negeri 2 Kota Ternate sangat cukup.

2. Pengaruh kegiatan literasi terhadap minat baca siswa kelas VIII SMP Negeri 2 Kota Ternate memiliki pengaruh sesuai dengan hasil data, menunjukan bahwa hasil tes siswa dengan interval nilai $60-69 \%$ atau sesuai pada aspek kesesuaian antara perencanaan dan peleksanaan kegiatan literasi terdapat 17 responden yang sesuai dan 10 siswa yang tidak sesuai 30-39\%. Aspek kelamaan kegiatan literasi pada pengaruh kegiatan literasi terhadap minat baca atau dapat dipersentasikan menjadi 56\% atau interval nilai 50-59 terdapat 15 responden yang sesuai, dan 12 responden yang tidak sesuai 44\%. Aspek perkembangan hasil kemampuan membaca siswa 16 responden sesuai atau interval nilai $50-59 \%$ dan 11 responden yang tidak sesuai dengan interval nilai 40-49\%. Dan aspek perencanaan ke tahap selanjutnya terdapat 15 responden yang sesuai atau interval nilai 50-59\% dan 12 responden dengan kualifikasi nilai $40-49 \%$ yang tidak sesuai. Dengan demikian scara keseluruhan dari empat aspek dengan interval nilai dengan persentase dapat dikategorikan "sedang" Pencapaian tujuan pendidikan 
adalah keinginan semua orang baik pendidik maupun peserta didik, olehnya itu dalam pebelajaran yang perlu diperhatikan adalah selain peran guru juga peran siswa yang perlu diperhatikan, agar pencapaian tujuan pembelajaran terutama minat bacabisa dinikmati dan dipahami oleh peserta didik. Diharapkan kepada teman-teman mahasiswa, guru dan para peminat pendidikan, perlu adanya menindaklanjuti penelitian ini agar dapat membedakan peran pembelajaran membaca terhadap pengaruh kegiatan literasi terhadap minat baca pada siswa dari hasil yang diperoleh.

\section{Daftar Pustaka}

Abidin, Yunus, Mulyati Tita, Yunansah Hana. (2017). Pembelajaran Literasi.

Arikunto suharsimi. Prosedur Penelitian. (2006). Jakarta

Bastiano, Sudarsana Undang. (2014). Pembinaan Minat Baca. Tanggerang: Universitas Terbuka.

Chaer Abdul. (2012). Lingistik Umum. Jakarta:Rineka Cipta

Mahsun. (2005). Metode Penelitian Bahasa. Jakarta: Raja Grapindo Persada.

Nurhadi. (2000). Bagaimana Meningkatkan Kemampuan Membaa. Bandung: CV Sinar Baru Offset.

Hasanah, dkk. (2011). Faktor Faktor Yang Menentukan Minat Baca. Bandung: Remadja Karya.

Jurnal. PENGARUH PROGRAM LITERASI TERHADAP MINAT BACA DAN PRESTASI BELAJAR SISWA DI SMP ISLAM AL-AZHAAR TULUNGAGUNG Ajeng Kristianti Lawalata

Kasiram. (2008). Metodelogi Penelitian. Jakarta.

Lawalata, A. K. dan Sholeh, M. (2019). Pengaruh Program Literasi Terhadap Minat Baca dan Prestasi Belajar Siswa di SMP Islam Al-Azhaar Tulungagung. Inspirasi Manajemen Pendidikan 7, No. 3.

Rosidi, Ajib. (2016). Pembinaan Minat Baca Bahasa Dan Sastra. Bandung: PT Remaja Rosdakya.

Sumadayo, Samsu. (2011). Strategi dan Teknik Pembelajaran Membaca. Yogyakarta: Graha Ilmu

Sugiyono. (2015). Metode Penelitian Pendidikan Kualitatif, Kuantitatif dan R\&D. Bandung:Alfabeta

Sukmadinata, Syaodih, Nana. (2010). Metode Penelitian Pendidikan. Bandung: Remaja Rosdakarya.

Tarigan. (2008) Membaca Sebagai Suatu Ketrampilan Berbahasa. Bandung: Angkasa

Widodo. (2015). Kompetensi Literasi. Bandung: Angkasa. 